\title{
Adipose-derived Expanded Mesenchymal Stem Cells SCM-010
}

National Cancer Institute

\section{Source}

National Cancer Institute. Adipose-derived Expanded Mesenchymal Stem Cells SCM-010. NCl Thesaurus. Code C160891.

A preparation of human adipose-derived mesenchymal stem cells (MSCs), that can potentially be used for eng raftment purposes in certain autoimmune disorders. Upon intrathecal administration, adipose-derived expanded mesenchymal stem cells SCM-010 migrate to the bone marrow. These MSCs are pluripotent and capable of differentiating along specific lineages and may activate the immune system and repair damage to the nervous system. 